\title{
Innovation and Foreign Ownership
}

\author{
Maria Guadalupe, Olga Kuzmina and Catherine Thomas
}

WEB APPENDIX: NOT FOR PUBLICATION

Table S1: Variable Definitions

\begin{tabular}{|c|c|c|}
\hline Variable & $\begin{array}{c}\text { Survey } \\
\text { Question } \\
\text { number }\end{array}$ & Question wording (highlighted as in the original questionnaire) \\
\hline Foreign & A11 & $\begin{array}{l}\text { State whether there was some foreign participation in the company's capital, directly or indirectly } \\
\text { (through a company in which over } 50 \text { percent of the capital is in foreign hands), and its percentage. }\end{array}$ \\
\hline $\begin{array}{l}\text { Process Innovation, } \\
\text { New Machines, New } \\
\text { Methods of } \\
\text { Organizing } \\
\text { Production, Both }\end{array}$ & E8 & $\begin{array}{l}\text { State whether the company introduced some important modification in the production process } \\
\text { (process innovation). If so, state whether it consisted of: } \\
\text { 1. Introduction of new machinery } \\
\text { 2. New methods for organizing production } \\
\text { 3. Both }\end{array}$ \\
\hline Product Innovation & E7 & $\begin{array}{l}\text { State whether the company has undertaken product innovations (completely new products, or with } \\
\text { such modifications that they are different from those produced earlier). }\end{array}$ \\
\hline $\begin{array}{l}\text { Assimilation of } \\
\text { Foreign Technologies }\end{array}$ & E3_3 & State whether the company carried out or contracted efforts for assimilating imported technologies. \\
\hline $\begin{array}{l}\text { Export via foreign } \\
\text { parent }\end{array}$ & F3_3 & $\begin{array}{l}\text { State whether the company used each one of the following mechanisms as a way of gaining access to } \\
\text { international markets: } \\
\text { 1. It has its own resources (agents' network, branch, delegation or affiliated company) } \\
\text { 2. It uses a parent company established abroad (companies with foreign capital) } \\
\text { 3. It uses a specialized intermediary established in Spain } \\
\text { 4. It participates in some kind of collective action for exporting (industry-wide export agreement, } \\
\text { exporters' association or export cooperatives) } \\
\text { 5. Other (specify) }\end{array}$ \\
\hline
\end{tabular}

Notes: Variable definitions are given as in the 2002 questionnaire, which is available at ftp://ftp.funep.es/ESEE/pet_extr/c-esee02.pdf. Firms are asked the same questions in other years. 
Table S2. The Selection Decision: Probit Specification

Productivity Measure

he sample period

Base year productivity

2nd quartile Base year productivity

2a

$0.363^{* * *}$

(0.0248)

$2 \mathrm{a}$

3

a

$4 a$

Ln Labor Productivity

3rd quartile Base year productivity

$0.997 * * *$

(0.255)

(0.0469)

$0.374^{* * *}$
$(0.0662)$

5 a

$6 \mathrm{a}$

4**

$(0.247)$

$2.011^{* * *}$

4th quartile Base year productivity

(0.239)

$0.410 * * *$

(0.100)

Exporting firm in base year

$(0.239)$

Exporting in base year*Base year productivity

Observations

Pseudo R-squared

\begin{tabular}{|c|c|c|}
\hline & $\begin{array}{r}3354 \\
0.222 \\
\end{array}$ & $\begin{array}{c}3354 \\
0.213 \\
\end{array}$ \\
\hline Ired in a given year & $1 \mathrm{~b}$ & $2 b$ \\
\hline & $\begin{array}{c}0.277 * * * \\
(0.0205)\end{array}$ & \\
\hline & & $\begin{array}{c}0.588 * * * \\
(0.193) \\
1.017 * * * \\
(0.183) \\
1.460 * * * \\
(0.179)\end{array}$ \\
\hline
\end{tabular}

\subsection{8}

$(0.0983)$

$-0.0977^{*}$

(0.0551)

3354

0.225

$(0.127)$
$0.473 * * *$
$(0.126)$

$0.684^{* * *}$

(0.123)

0.07

$3 \mathrm{~b}-2.00$

Panel B: The probability of being acquired in a given year

Lagged productivity

$0.330 * * *$

$4 \mathrm{~b}$

(0.0377)

$(0.0659)$

2nd quartile Lagged productivity

3rd quartile Lagged productivity

4th quartile Lagged productivity

Lag Exporting firm

Lag Exporting firm*Lagged productivity

Observations

Pseudo R-squared

0.104

(0.0856)

$-0.0903 * *$

(0.0444)

$19786 \quad 19786 \quad 19750$

$\begin{array}{lll}19786 & 19786 & 19750 \\ 0.174 & 0.161 & 0.173\end{array}$

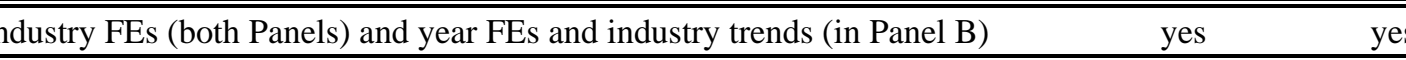

Industry FEs (both Panels) and year FEs and industry trends (in Panel B) $\quad$ yes $\quad$ yes

yes

\begin{tabular}{lcc}
\hline \hline Industry FEs (both Panels) and year FEs and industry trends (in Panel B) & yes & yes
\end{tabular}

Notes: Foreign is an indicator variable that equals one if the firm has at least 50-percent foreign ownership. Base year (lagged) ln Sales is the natural logarithm of the firm's real sales, relative to the industry mean, in the first year the firm appears in the sample (one year prior to the dependent variable). Base year (lagged) labor productivity is the natural logarithm of real value added per worker, relative to the industry mean, in the first year the firm appears in the sample (one year prior to the dependent variable). Exporting firm in base year equals one if the firm was an exporter in the first year it appears in the

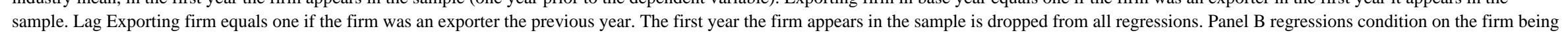
not foreign-owned in the previous year. Standard errors are clustered by firm. * indicates $10 \%$ significance; ** $5 \%$ significance; *** $1 \%$ significance. 
Table S3: Productivity Regressions Including Innovation Variables

\begin{tabular}{lccc}
\hline & $\begin{array}{c}\text { Ln Value Added } \\
(1)\end{array}$ & $(2)$ & $(3)$ \\
\hline \hline Ln Capital & $0.102^{* * *}$ & $0.116^{* * *}$ & $0.116^{* * *}$ \\
& $(0.0131)$ & $(0.0127)$ & $(0.0231)$ \\
Ln Labor & $0.723^{* * *}$ & $0.730^{* * *}$ & $0.759^{* * *}$ \\
& $(0.0285)$ & $(0.0282)$ & $(0.0542)$ \\
Process Innovation & $0.0247^{* * *}$ & & \\
& $(0.00315)$ & & \\
Product Innovation & & $0.0197^{* * *}$ & \\
& & $(0.00317)$ & \\
Assimilation of Foreign Technologies & & & $0.0975^{* * *}$ \\
& & & $(0.0270)$ \\
\hline Firm FEs & yes & yes & yes \\
Observations & 19529 & 19529 & 5170 \\
R-squared & 0.261 & 0.258 & 0.292 \\
\hline
\end{tabular}


Column 1 presents univariate probit regressions of the Foreign ownership dummy on the set of lagged variables used in the propensity score estimation, on all industries pooled (for the results shown in the paper, we estimate the propensity score by industry, to allow for different coefficients on the included variables). Column 2 presents the multivariate probit regression using the same variables, on all industries pooled. All regressions include industry dummies. The right-hand side variables are highly correlated, so that when we run the multivariate regression, many of them become insignificant. Note that lagged firm sales is the most significant determinant, consistent with our model. In the paper, the propensity score weights are obtained by estimating the multivariate regression for each industry separately. All regressors are balanced in all industries using the set of covariates in Column 2. When we used a more parsimonious specification, with fewer variables, some of the regressors were not balanced across blocks in some industries. These results are shown in Table S5, for a simpler specification of the propensity score.

Table S4: Probit model for propensity score estimation

\begin{tabular}{lcc}
\hline & Foreign & Foreign \\
& Univariate & Multivariate \\
\hline \hline Lag ln sales & 1 & 2 \\
\hline Lag labor productivity & $0.240^{* * *}$ & $0.180^{* *}$ \\
& $(0.0245)$ & $(0.0906)$ \\
Lag Sales growth & $0.260^{* * *}$ & -0.0987 \\
& $(0.0619)$ & $(0.0840)$ \\
Lag export status & -0.0990 & -0.185 \\
& $(0.117)$ & $(0.149)$ \\
Lag average wage & $0.498^{* * *}$ & 0.109 \\
& $(0.0889)$ & $(0.108)$ \\
Lag Innovation & $6.20 \mathrm{e}-07$ & $1.27 \mathrm{e}-07$ \\
& $(3.77 \mathrm{e}-07)$ & $(6.06 \mathrm{e}-07)$ \\
Lag Stock of Innovation & $0.221^{* * *}$ & 0.0717 \\
& $(0.0752)$ & $(0.0953)$ \\
Lag ln capital & 0.0171 & $-0.0336^{*}$ \\
& $(0.0132)$ & $(0.0200)$ \\
Lag ln capital per worker & $0.215^{* * *}$ & 0.0537 \\
Year & $(0.0217)$ & $(0.0938)$ \\
Industry FEs & $0.284^{* * *}$ & 0.0945 \\
Observations & $(0.0389)$ & $(0.0938)$ \\
Pseudo R-squared & & -0.0188 \\
& & $(0.0115)$ \\
& & yes \\
& 15417 & 15417 \\
& & 0.151 \\
\hline
\end{tabular}


This table re-estimates the propensity score regressions in the paper, using a parsimonious specification for the propensity score that includes only Lagged firm sales, Lagged labor productivity and year as controls when calculating the score. The score is again calculated by industry, to allow for differences across industries in the coefficients. In this case, the covariates are not balanced in some industries and blocks, which is why we chose a richer specification for the paper, where all covariates are balanced. However, as the table shows, the results are fairly robust when using this simpler specification for the score.

Table S5: Propensity score estimation when using only Lag Sales and Lag Labor Productivity in the score

\begin{tabular}{|c|c|c|c|}
\hline Corresponding Col in Paper & $\begin{array}{c}\text { Process Innovation } \\
\text { Table } 3 \text { Col 5a } \\
\end{array}$ & $\begin{array}{c}\text { Product Innovation } \\
\text { Table } 3 \text { Col 5b } \\
\end{array}$ & $\begin{array}{c}\text { Assimilation of Foreign } \\
\text { Technologies } \\
\text { Table 3 Col 5c } \\
\end{array}$ \\
\hline \multirow[t]{2}{*}{ Lag Foreign } & $0.473^{* *}$ & 0.142 & 0.0867 \\
\hline & $(0.194)$ & $(0.207)$ & $(0.0577)$ \\
\hline Observations & 20545 & 20545 & 5406 \\
\hline \multirow[t]{3}{*}{ R-squared } & 0.523 & 0.392 & 0.177 \\
\hline & Both & New Machines & New Organization \\
\hline & Table 4 Col 5a & Table 4 Col 5b & Table 4 Col 5c \\
\hline \multirow[t]{2}{*}{ Lag Foreign } & $0.353^{* *}$ & -0.105 & $0.225^{* *}$ \\
\hline & $(0.154)$ & $(0.0927)$ & $(0.104)$ \\
\hline Observations & 20545 & 20545 & 20545 \\
\hline \multirow[t]{3}{*}{ R-squared } & 0.266 & 0.372 & 0.153 \\
\hline & Exports/Sales & ln Exports & ln Average wage \\
\hline & Table 7 Col 5a & Table 7 Col 5b & Table 7 Col 5c \\
\hline \multirow[t]{2}{*}{ Lag Foreign } & 0.0356 & 0.162 & $0.0426^{*}$ \\
\hline & $(0.0252)$ & $(0.178)$ & $(0.0250)$ \\
\hline Observations & 20506 & 10808 & 20541 \\
\hline \multirow[t]{3}{*}{ R-squared } & 0.066 & 0.140 & 0.240 \\
\hline & ln Sales & ln Labor Productivity & \\
\hline & Table 8 Col 6a & Table 8 Col 6b & \\
\hline \multirow[t]{2}{*}{ Lag Foreign } & $0.124 * *$ & 0.0596 & \\
\hline & $(0.0532)$ & $(0.0572)$ & \\
\hline Observations & 20545 & 20245 & \\
\hline R-squared & 0.104 & 0.017 & \\
\hline Firm FEs & yes & yes & yes \\
\hline Propensity score weighting & yes & yes & yes \\
\hline
\end{tabular}


Table S6. Foreign Ownership and Innovation: Restricted Sample

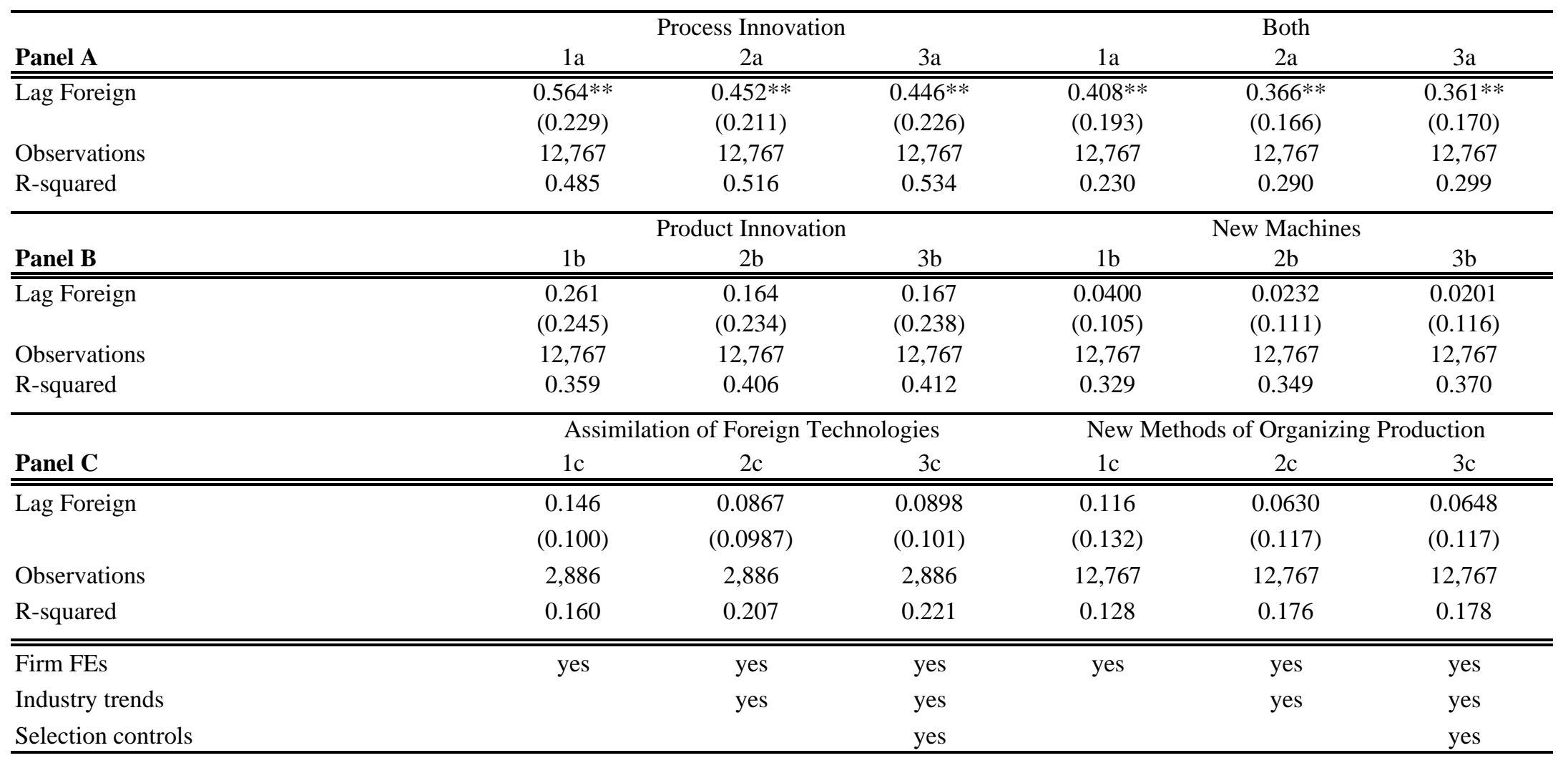

Notes: Foreign is an indicator variable that equals one if the firm has at least 50-percent foreign ownership. The dependent variables are our measures of innovation (see Section 3 for details). Selection controls include lagged ln firm sales, lagged ln labor productivity, lagged sales growth, lagged export status, lagged average wage, lagged ln capital per employee, lagged ln capital. The sample includes only observations when contemporaneous and forward Foreign as well as all selection controls are nonmissing, and coincides with the sample in column 4 of Tables 3 and 4, respectively. All columns include year fixed effects. Standard errors are clustered by firm. * indicates $10 \%$ significance; $* * 5 \%$ significance; *** $1 \%$ significance. 
Table S7. Access to Export Channel and Innovation: Restricted Sample

\begin{tabular}{|c|c|c|c|c|}
\hline \multirow[b]{2}{*}{ Panel A } & \multicolumn{2}{|c|}{ Process Innovation } & \multicolumn{2}{|c|}{ Product Innovation } \\
\hline & За & $4 a$ & $1 \mathrm{a}$ & 2a \\
\hline \multirow{2}{*}{ Export via foreign parent } & $0.954 * * *$ & $0.853 * * *$ & $0.815 * * *$ & $0.792 * * *$ \\
\hline & $(0.304)$ & $(0.288)$ & $(0.260)$ & $(0.271)$ \\
\hline \multirow[t]{2}{*}{ Export } & 0.209 & 0.198 & 0.0261 & 0.0627 \\
\hline & $(0.129)$ & $(0.129)$ & $(0.121)$ & $(0.115)$ \\
\hline \multirow[t]{2}{*}{ Lag Foreign } & 0.828 & 0.612 & -0.134 & -0.186 \\
\hline & $(0.648)$ & $(0.584)$ & $(0.434)$ & $(0.379)$ \\
\hline \multirow[t]{2}{*}{ Export*Lag Foreign } & -0.237 & -0.249 & 0.0415 & -0.146 \\
\hline & $(0.672)$ & $(0.611)$ & $(0.513)$ & $(0.455)$ \\
\hline Observations & 4,096 & 4,096 & 4,096 & 4,096 \\
\hline R-squared & 0.485 & 0.517 & 0.359 & 0.409 \\
\hline
\end{tabular}

\begin{tabular}{|c|c|c|c|c|}
\hline \multirow[b]{2}{*}{ Panel B } & \multicolumn{2}{|c|}{ Both } & \multicolumn{2}{|c|}{ Assimilation of Foreign Technologies } \\
\hline & $3 b$ & $4 \mathrm{~b}$ & $1 \mathrm{~b}$ & $2 b$ \\
\hline \multirow[t]{2}{*}{ Export via foreign parent } & $0.848^{* * *}$ & $0.752^{* * *}$ & $\overline{0.297 * *}$ & $0.282^{* *}$ \\
\hline & $(0.281)$ & $(0.251)$ & $(0.116)$ & $(0.114)$ \\
\hline \multirow[t]{2}{*}{ Export } & 0.0809 & 0.0683 & 0.0245 & 0.0253 \\
\hline & $(0.0821)$ & $(0.0800)$ & $(0.0257)$ & $(0.0254)$ \\
\hline \multirow[t]{2}{*}{ Lag Foreign } & 0.0183 & -0.146 & $0.149 * *$ & 0.117 \\
\hline & $(0.451)$ & $(0.419)$ & $(0.0725)$ & $(0.0738)$ \\
\hline \multirow[t]{2}{*}{ Export*Lag Foreign } & 0.241 & 0.345 & -0.132 & -0.143 \\
\hline & $(0.475)$ & $(0.444)$ & $(0.0975)$ & $(0.0972)$ \\
\hline Observations & 4,096 & 4,096 & 4,096 & 4,096 \\
\hline R-squared & 0.238 & 0.301 & 0.172 & 0.210 \\
\hline Firm FEs & yes & yes & yes & yes \\
\hline Industry trends & & yes & & yes \\
\hline
\end{tabular}

Notes: Export is an indicator variable that equals one if the firm exports any goods. Export via foreign parent is an indicator variable that equals one if the firm declares that it exports through a foreign parent. Foreign is an indicator variable that equals one if the firm has at least 50-percent foreign ownership. The dependent variables are our measures of innovation (see Section 3 for details). Selection controls include lagged ln firm sales, lagged ln labor productivity, lagged sales growth, lagged export status, lagged average wage, lagged log capital per employee, lagged log capital. The sample includes only observations when all selection controls are non-missing, and coincides with the sample in columns 5 and 3 of Tables 5 and 6, respectively. All columns include year fixed effects. Standard errors are clustered by firm. * indicates $10 \%$ significance; ** 5\% significance; *** $1 \%$ significance. 